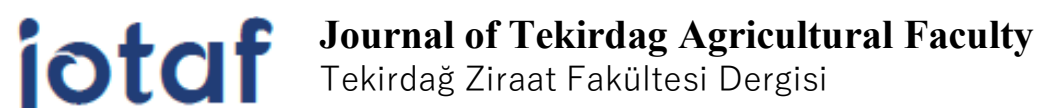

\section{Technical Efficiency and Profitability of Cassava Production in Delta State: A Stochastic Frontier Production Function Analysis}

\section{Theophilus Miebi GBIGBI}

\begin{abstract}
The study empirically examines the production efficiency of cassava farmers in Delta State, Nigeria, using stochastic frontier analysis. A multi-stage sampling procedure was used to select 120 farmers. The result showed that $68.3 \%$ of cassava farmers fell within the age range of $40-59$ years, majority $(63.3 \%)$ of them were females, $69.2 \%$ had formal education, $51.7 \%$ had $6-10$ years farming experience, $62.5 \%$ had household size of $6-10$ persons, $70 \%$ did not belong to cooperative society, $88.3 \%$ of them had farm size between $0.1-0.9$ ha, $76.7 \%$ did not have access to credit and $74.2 \%$ also did not have extension contact. A mean technical efficiency of $67 \%$ was recorded. The results imply that the average efficiency of cassava production could be improved by $33 \%$ through better use of existing resources and technology. The result showed that the return to scale was 1.306. The gamma coefficient was 0.86 , implying that $86 \%$ of variation of cassava output from the production frontier was accounted by the technical inefficiency of the farmers. The major factors which influenced the farmers technical efficiency were farm size, planting material and capital while farming experience, level of education, access to credit, gender, age of farmer and household size exerted a significant effect on their inefficiency level. The major problems faced by the farmers were inadequate finance, inaccessibility to credit, inadequate access to improved varieties and high cost of inputs. The study deduced that the gross margin and net farm incomes were $\$ 155,726.34$ a and $\$ 147,464.84$ with BCR of $\$ 2.38$, suggesting that cassava production is profitable. It is recommended that more farmers should venture into cassava production as a means of wealth creation and employment generation.
\end{abstract}

Keywords: Cassava production, Smallholder farmers, Stochastic frontier model, Socio-economic.

\footnotetext{
1*Sorumlu Yazar/Corresponding Author: Theophilus Miebi GBIGBI, Department of Agricultural Economics and Extension, Delta State University Asaba Campus. PMB 95074, Asaba. E-mail: gbigbitheophilusmiebi@yahoo.com (DD OrcID: 0000-0002-1335-7231

Atıf/Citation: GBIGBI T.M.. Technical Efficiency and Profitability of Cassava Production in Delta State: A Stochastic Frontier Production Function Analysis. .Journal of Tekirdag Agricultural Faculty, 18 (1), 21-31.

CBu çalışma Tekirdağ Namık Kemal Üniversitesi tarafından Creative Commons Lisansı (https://creativecommons.org/licenses/by-nc/4.0/) kapsamında yayınlanmıştır. Tekirdağ 2021
} 


\section{Introduction}

In Nigeria, agriculture has contributed almost 60 percent of GDP and greater than 70 percent of foreign exchange income. Cassava is the most important food-processed cash crop of resource-limited farmers in Africa, Asia, Latin America and Caribbeans. In addition to contributing to the Gross Domestic Product, it is the greatest non-oil export earner, the greatest agency of labour, and the biggest contributor to the introduction of wealth and the alleviation of poverty, as massive share of the populace derives its earnings from agriculture and related activities (Yakubu and Akanegbu, 2015).It is grown in virtually all parts of the' country and is now the local food crop for foreign exchange earnings (Onyenwoke and Simonyan 2014). Cassava is the perfect food security crop for sub-Saharan Africa because of its capacity to produce in poor environments. Cassava can be cultivated with minimal inputs, but produces substantially more fertilizer and better management production.

Cassavas play a major role in agriculture, particularly in sub-Saharan Africa, as they grow on poor soils and low rainfall. It's a crop that can be harvested perennially as needed. It has a remarkable capacity to withstand and recover from the pressure of biotics and abiotics. Cassava acts as a hunger buffer to reduce farmers ' poverty. Nigeria is currently the world's largest producer of cassava, generating one-third more than Brazil, almost doubling Thailand and Indonesia's production capacity and producing around five million metric tons per year (FAO, 2013, Anyanwu et al., 2015). This increase in production was attributed to a host of factors such as; the availability of many improved varieties of cassava following the research effort of I1TA, the joint effort of African leaders through the New Partnership for Africa's Development (NEPAD), the Presidential cassava production Initiative for agricultural transformation through which basic farm inputs were made available to farmers (Ahmed-Hameed et al., 2017).

Nigeria, cassava has a wide range of uses. Today, cassava is moving from a mere surviving crop in the farmer field to a commercial plantation crop. This exponential growth of this crop is attributable to its finding as a cheap source of edible carbohydrates which can be consumed in raw or processed form as foods like garri, fufu, tapioca, starch, pellets, carbohydrate, alcohol biofuel for vehicles, flour and chips. In Nigeria, the majority of cassava produced (90\%) is used for human food (IITA, 2010, Kamaljit and Preeti, 2017). Owing to the wide range of uses to which cassava is put, there is an excessive demand' pressure in its production. In spite of the central position occupied by cassava in addressing rural poverty, the smallholder peasants who produce the bulk of cassava in Nigeria continue to be economically inefficient in terms of resources management.

However, cassava farms are categorized by very low productivity, just like other crop farmers, which is a key issue in Nigeria's agriculture. The problem of decreasing crop efficiency relies upon on the stage of competence of farmers in the utilization of productive resources. It is generally agreed that farmers can increase and sustain their agricultural production within the context of existing resources and available technologies by increasing agricultural productivity through the competence of usage of resources (Fan et al., 2012). This finding has therefore been the main reason why a major economic study has continued to be carried out on agricultural efficiency in Nigeria in particular, with limitable resources and opportunities for developing and applying better technologies (Girei et al., 2014). Recent observations have shown that cassava production in Delta State is significantly deteriorating, owing to poor planting materials, insufficient funding, lack of information, farm size, fluctuations in season, inappropriate technology, poor road transport networks, high inputs cost and manual operations.

Technical efficiency means the ability of a given input and production technology to attain the optimum level of output. The ability of a farm to produce a certain production level with the lowest resources is farm efficiency. The optimal way to produce a commodity is to use the lowest amount of resources to achieve a certain production level (Ogunyinka and Ajibefun ,2003).To reach an optimal production level, resources must be made available and the resources available should be used effectively. Successful results-oriented agricultural development and strategies require knowledge of farm supply productivities to identify the resources whose quantity or use level should be amplified or reduced (Agbontale and Issa, 2011). Based on this, the focus is now on cassava production by small scale farmers, who make up the majority of Nigeria's farmers (Ojimba, 2017).

Small-scale farmers contributing the bulk of agricultural production must be aided by effective use of their production resources to produce higher profitability above subsistence levels. The evaluation of technical efficiency gives policymakers more knowledge to enhance understanding among farmers. Indeed, farmers ' technical efficiency level has significant implications for the development strategies of the primary sector. 
Therefore, an understanding of the level of profitability and technical efficiency as well as its relationship with farmers and farm features can help farmers to exploit their potential and take critical measures to improve their profitability and efficiency. It is in this context that the objective of this study is to estimate the profitability and technical efficiency of farmers with cassava production determinants in Delta State, Nigeria, with a view to increasing resource efficiency.

\section{Materials and Methods}

The study was conducted in Delta State. Due to the large percentage of farmers involved and the government's initiative to increase food sufficiency through the cultivation of cassava, this location was chosen for the study. An unsystematic sampling procedure was adopted on a multi-stage basis. The first stage consists of choosing the three agro-geopolitical areas, Delta South, Delta North and Delta Central. Two Local Government Areas from each of the zones were later chosen. Isoko North, Bomadi, Ethiope West, Ughelli Central, Ukwuani and Ika South are the designated local government areas. A total of eighteen communities were carefully chosen from each of the LGAs. From the list of cassava farmers issued by the Delta Agricultural and Rural Development Authority (DARDA) extension agents, seven (7) farmers were selected randomly from the above-mentioned communities, giving a total of one hundred and twenty-six (126) respondents with the help of a standardized questionnaire. However, six questionnaires were discarded due to lack of information. Therefore, only information from 120 respondents were used for the study.

Data collected for the study were analyzed using simple descriptive statistics, costs and returns analysis as well as stochastic frontier production function. This model concerns itself with the estimation of frontiers that enveloped the data rather than those intersecting the data (Kumbhakar and Lovell, 2000). The stochastic frontier function can be written by the following equation 1 ;

$Y i=f(X i, \beta) \exp (V i-U i)$

In cases in which $\mathrm{Yi}$ is the output of the $\mathrm{ith}$ farm, $\mathrm{Xi}$ is a input vector used by the ith farm; $\beta$ is a vector with unspecified parameters, $\mathrm{Vi}$ is an allegedly separate, identically distributed variable (iid) $\mathrm{N}\left(0, \sigma_{\mathrm{v}}{ }^{2}\right)$ and independent of $\mathrm{Ui}$ and $\mathrm{Ui}$ is an alleged random variable that is believed to account in the production of the ith farm for technical inefficiency.

The farm specific stochastic production function frontier representing the maximum possible output $\left(\mathrm{Y}^{*}\right)$ can be expressed by the following equation 2 ;

$Y i * f(X i ; \beta)+(V i)$

Equation (1) may be rewritten using equation (2) by the following equation 3;

$\mathrm{Y} i=Y i * \exp (-U i)$

Thus the efficiency of the ith farm denoted by TEi is given by the following equation $(4,5$ and 6$)$

$$
\begin{aligned}
& T E i=\frac{Y i}{Y i} *=\exp (-U i) \\
& =f(X i ; \beta) \exp (V i-U i) / f(X i ; \beta) \exp (V i) \\
& =\exp (-U i)
\end{aligned}
$$

Where $\mathrm{Yi}$ is the observed output and $\mathrm{Y}_{1}{ }^{*}$ is the frontier output. The difference between $\mathrm{Y}$ and $\mathrm{Y}_{1} *$ is thus incorporated into $\mathrm{Ui}$. The $\mathrm{Y}$ is equal to $\mathrm{Yi}$ if $\mathrm{Ui}=0$. This means that production is located on the stochastic frontier and therefore technically efficient and that given the level of input the farm achieves its maximum output. If U1 > 0 is below the frontier, development suggests that the farmer is technically inefficient (Battase and Coelli, 1995).

Given our research objectives, the generalized stochastic frontier model can be expressed for the cassava farmers by the following equation $7 ;$ :

In $Y_{i j}=B_{0}+B_{1} \operatorname{In} X_{1 i j}+B_{2} \operatorname{In} X_{2 i j}+B_{3} \operatorname{In} X_{3 i j}+B_{4} \operatorname{In} X_{4 i j}+V_{i j}-U_{i j}$

Where; subscript $\mathrm{ij}$ refers to the $\mathrm{j}^{\text {th }}$ observation of the $\mathrm{i}^{\text {th }}$ farmer. 
In = Logarithm to base e,

$\mathrm{Y}=$ Total output of Cassava $(\mathrm{kg})$

$\mathrm{X}_{1}=$ Farm size $(\mathrm{ha})$

$\mathrm{X}_{2}=$ Labour Used (Man-days)

$\mathrm{X}_{3}=$ Planting materials $(\mathrm{kg})$

$\mathrm{X}_{4}=$ Capital ( $)$

\section{The efficiency Model}

It is unnecessary to know farmers ' degree of technically inefficient without identifying sources of farm inefficiency (Coelli, 1996). Consequently, the second stage of this analysis therefore examines the sources of the farmers ' technical inefficiency at farm level.

Inefficiency effects are believed to be distributed separately and $U$ is caused by truncation (at zero) of Mean $\mathrm{U}_{\mathrm{ij}}$ 's normal distribution.

Where $U_{i j}$ is defined by the following equation 8 ;

$U i=\beta 0+\beta 1 Z 1+\beta 2 Z 2+\beta 3 Z 3+\beta 4 Z 4+\beta 5 Z 5+e 1$

where; $U_{i}=$ Technical inefficiency of the $i^{\text {th }}$ farmer

$\mathrm{Z}_{1}=$ Years of experience of the $\mathrm{i}^{\text {th }}$ farmer in Cassava Production

$\mathrm{Z}_{2}=$ Formal education of the $\mathrm{i}^{\text {th }}$ farmer

$Z_{3}=$ Credit accessibility ( 1 for access to credit and 0 otherwise $)$

$Z_{4}=$ Contact and meeting with extension services (Number of visits in the cropping season)

$\mathrm{Z}_{5}=$ Age of farmers (yrs)

$\mathrm{Z}_{6}=$ Household size (persons)

$\mathrm{Z}_{7}=$ Gender $($ dummy, male $=1$, otherwise $=0)$ )

The $\beta, \mathrm{Z}$ and $\gamma$ coefficients are unknown parameters to be estimated, by the method of maximum likelihood, using the Computer Programme Frontier Version 4.Ic (Coelli, 1996) along with various parameters which are expressed with respect of $Z^{2}-Z v+Z u^{2}, \gamma$ (gamma) $Z u^{2} / Z^{2}$ and $\gamma$ has a value of between 0 and one.

\section{Results and Discussion}

\subsection{Socio-economic attributes of the farmers}

Table 1 present the socio-economic attributes of the farmers. The result indicated that majority $(68.3 \%)$ of the respondents were in the age bracket of $40-59$ years. About $25 \%$ of them were between $60-79$ years while $6.7 \%$ of the farmers range between 20-39 years. The reason of older people leading cassava production might be as a result of youth migration from rural to urban in search of white collar jobs. Similar to this finding, Onyedicachi (2015) found a mean age of 40.79 amongst farmers in Abia State, Nigeria. The result showed that majority $(63.3 \%)$ were female while $36.7 \%$ were male. This shows that cassava production was mostly operated by women in the study area. This is likely to have a direct relationship on efficiency since women are good at supervision and follow-up of farming operations (Berhanu and Beliyu 2015). The result indicated that most $(37.5 \%)$ of the respondents had primary education. The result further showed that $27.5 \%$ and $4.1 \%$ had secondary and tertiary education respectively while $30.8 \%$ had no formal education. This means $69.2 \%$ were literate. This high educational level implies that efficiency can be enhanced with relative ease (Osun et al. 2014, Durojaye and Ogunjinmi 2015). This is possible because educated farmers are capable of evaluating and understanding innovations. The result further showed that $51.7 \%$ of the respondents had farming experience of $6-10$ years, $37.5 \%$ of them had farming experience of 11 years and above. And only $10.8 \%$ had 1-5years farming experience. This is in line with the results of Komolafe et al. (2014), who found high farming experience among farmers. This suggest that experience 
farmers are likely to be efficient than less experienced farmers, given their acquisition of practical knowledge of farm business.

Most of the respondents (62.5\%) had household size of between 6-10 persons. About $28.3 \%$ of them had household sizes ranging between $1-5$ persons while only $9.2 \%$ had household size of 11 persons and above. The household size could serve as source of cheap labour. This is congruent with Idrisa et al (2012) that large household sizes ensure adequate supply of family labour for farm production activities. According to membership of association, majority (70\%) did not belong to any organization. This is likely to impact negatively on their level of their efficiencies. The result indicated that majority $(88.3 \%)$ of the respondents had farm size between $0.1-0.9$ ha. About $9.2 \%$ of the respondents farm size within the range of 1.0-2.0ha and only $2.5 \%$ of them had farm size of between 2.1-3.0 ha. This finding corroborates that of Issa et al (2016) who found that maize farmers operate on small scale. The result also revealed that $76.7 \%$ of respondents did not access credit while only $23.3 \%$ accessed credit. This invariably translates into an unproductive use of resources. The result revealed that $74.2 \%$ of respondents had no interaction with extension workers. This could affect the use of better cassava production technologies.

Table 1. Socioeconomic characteristics of farmers in the study $(N=120)$

\begin{tabular}{|c|c|c|}
\hline Variable & Frequency & Percentage \\
\hline \multicolumn{3}{|l|}{ Age (years) } \\
\hline $20-39$ & 8 & 6.7 \\
\hline $40-59$ & 82 & 68.3 \\
\hline $60-79$ & 30 & 25.0 \\
\hline \multicolumn{3}{|l|}{ Gender } \\
\hline Male & 44 & 36.7 \\
\hline Female & 76 & 63.3 \\
\hline \multicolumn{3}{|l|}{ Educational level } \\
\hline No formal education & 37 & 30.8 \\
\hline Primary education & 45 & 37.5 \\
\hline Secondary education & 33 & 27.5 \\
\hline Tertiary education & 5 & 4.1 \\
\hline \multicolumn{3}{|c|}{ Farming experience (years) } \\
\hline $1-5$ & 13 & 10.8 \\
\hline 6-10 & 62 & 51.7 \\
\hline 11 and above & 45 & 37.5 \\
\hline \multicolumn{3}{|l|}{ Household size } \\
\hline $1-5$ & 34 & 28.3 \\
\hline $6-10$ & 75 & 62.5 \\
\hline 11 and above & 11 & 9.2 \\
\hline \multicolumn{3}{|c|}{ Membership of association } \\
\hline Member & 36 & 30.0 \\
\hline Non-member & 84 & 70.0 \\
\hline \multicolumn{3}{|l|}{ Farm size (ha) } \\
\hline $0.1-0.9$ & 106 & 88.3 \\
\hline $1.0-2.0$ & 11 & 9.2 \\
\hline $2.1-3.0$ & 3 & 2.5 \\
\hline \multicolumn{3}{|l|}{ Credit access } \\
\hline Access & 28 & 23.3 \\
\hline No access & 92 & 76.7 \\
\hline \multicolumn{3}{|l|}{ Extension contact } \\
\hline Contact & 31 & 25.8 \\
\hline No contact & 89 & 74.2 \\
\hline
\end{tabular}




\subsection{Production Function Analysis}

The results of the stochastic frontier function are presented in Table 2. The stochastic frontier model's parameter estimates show that only three determinants of cassava production such as farm size, planting material and capital differed significantly from zero. The farm size coefficient was significant at a level of $1 \%$ and its coefficient was positive. This indicates that an upsurge in farm size would lead to an increase in cassava production. This conforms to Krishna et al (2016) findings that farm sizes had positive effects on efficiency. The coefficient of planting materials was positive which conformed to a priori expectation and this resource was significant at $5 \%$ level. This shows that increased planting materials would increase cassava output. The result concurs with (Ezeibe et al 2015). The coefficient of capital was positive which conformed to a priori expectation and this resource was important at $1 \%$ level. This infers that increased capital would lead to increase in cassava output.

Table 2. Maximum likelihood estimation of the cobb-douglas stochastic production function

\begin{tabular}{lllll}
\hline Variable & Parameter & Coefficient & Standard error & t-value \\
\hline Production factors & & & \\
\hline Constant & $\mathrm{B}_{0}$ & 5.620 & 0.612 & $9.183^{* * *}$ \\
\hline Farm size & $\mathrm{B}_{1}$ & 0.437 & 0.041 & $10.659^{* * *}$ \\
\hline Labour & $\mathrm{B}_{2}$ & 0.210 & 0.119 & 1.765 \\
\hline Planting material & $\mathrm{B}_{3}$ & 0.516 & 0.204 & $2.529^{* *}$ \\
\hline Capital & $\mathrm{B}_{4}$ & 0.143 & 0.033 & $4.333^{* * *}$ \\
\hline Inefficiency effects & & & $2.553^{* *}$ \\
\hline Constant & $\mathrm{Z}_{0}$ & 2.387 & 0.935 & $3.260^{* * *}$ \\
\hline Farming experience & $\mathrm{Z}_{1}$ & -2.246 & 0.689 & $3.420^{* * *}$ \\
\hline Education & $\mathrm{Z}_{2}$ & -0.701 & 0.205 & $2.824^{* *}$ \\
\hline Credit access & $\mathrm{Z}_{3}$ & -0.048 & 0.017 & 0.398 \\
\hline Extension contact & $\mathrm{Z}_{4}$ & 0.240 & 0.603 & $3.626^{* * *}$ \\
\hline Age of farmers & $\mathrm{Z}_{5}$ & 0.754 & 0.163 & $2.861^{* * *}$ \\
\hline Household size & $\mathrm{Z}_{6}$ & 1.592 & 0.470 & 2.183 \\
\hline Gender & $\mathrm{Z}_{7}$ & -0.206 & 0.072 & 2.482 \\
\hline Sigma-squared & & 0.603 & 0.276 & \\
\hline Gamma & & 0.861 & 0.347 & \\
\hline Log-likelihood function & 54.140 & & \\
\hline$* * * * *$ significant at $1 \%$ and $5 \%$ probability level & & & \\
\hline
\end{tabular}

The result shows that farming experience was negative. This shows that the years of farming experience decreases technical inefficiency of the farmers, hence, its effect on the technical efficiency increases with more years spent in farming. The variable education was negative. This indicates that the literacy level of cassava farmers decreases the technical inefficiency of the farmers. This suggests that educated farmers use productive resources efficiently to maximize production, presumably due to their enhanced technical knowledge acquisition. This result is congruent with Akerele et al (2018). The variable access to credit is negative and statistically meaningful with technical inefficiency of the respondents. The implication is 'that farmers with more access tend to have higher competence level than those with less access to credit. in cassava. The farmers access to credit at the right time and amount received helps acceptance of better technologies and timely procurement of planting materials which will lead to higher level of farm efficiency and output. The inefficiency estimates indicate that age of farmers was positive and complied with a priori expectation. This indicates that the farmers age increases technical inefficiency, which implies that age decreases the technical efficiency of the farmers. Given the aging nature of farmers in the study area, this finding is not surprising. This is so because aged farmers lack vigor and stamina required to accomplish cassava production tasks which are not only labour intensive and time consuming but done manually. The variable household size has a positive relationship with technical inefficiency status of the farmers. This indicates that the household size increases technical inefficiency of the farmers. This could be that the respondents did not judiciously utilized the available family labour in the farm. The variable gender has negative relationship with technical inefficiency. This indicates that the males are more technically efficient than the female counterparts. This is consistent with a priori expectation. This result can be explained by the 
phenomenon that cassava production is very tedious requiring strength to cope which the men are more capable. The result is also congruent with Ekunwe et al (2018) that correlation exist between gender of household head and technical efficiency.

\subsection{Technical efficiency analysis}

The result of the technical efficiency analysis are presented in Table 3. The findings of evaluation of the technical output of the producers showed that there was a significant technical inefficiency in cassava production as indicated by a 5 percent gamma value of 0.861 . This implies that about $86.1 \%$ variation in the output of farmers was due to differences in their technical efficiency. As evidenced in Table 3, the estimated technical efficiency varies widely among the sample cassava farmers ranging from 0.47-0.94 with mean technical efficiency of 0.67. The highest range of farms technical efficiency was $0.71-0.80$ representing $60 \%$ of the sample farmers followed by $0.81-0.90(21.7 \%)$ and the lowest range of technical efficiency was less than $0.50(2.5 \%)$ while only $3.3 \%$ have an efficiency level of above $90 \%$. On the average, an average cassava farmer in the study area is able to obtain only $67 \%$ of cassava output from his input combination. This suggests that the average cassava farmer was $33 \%$ far away from the frontier technical efficiency (100\%) given the existing technology in the area. The broad variance in technical efficiency estimates indicate that majority of farmers often make inefficient use of their resources during the production process and possibilities are still available to increase their current level of technical performance. By implication, this result shows that in the short run, cassava output can be enhanced by $67 \%$ through the adoption of improved cassava production technologies and sound farm management practices. It can be concluded that an average cassava farmer in the area of the study can realize $28.7 \%$ cost saving (i.e. 1 $(67 / 94) \times 100)$ in order to achieve its most efficient technical efficiency. In order to achieve the most productive level of technical efficiency, a cassava farmer must also achieve 50\% (i.e. 1-(46/94) x 100) cost savings. The result supports Nwike and Ugwumba (2016) who reported different levels of inefficiency in resource use among cassava farmers in Nigeria.

Table 3.Technical efficiencies of sampled cassava farmers

\begin{tabular}{lll}
\hline Efficiency level & Frequency & Percentage \\
\hline$<0.50$ & 3 & 2.5 \\
$0.50-0.60$ & 6 & 5.0 \\
$0.61-0.70$ & 9 & 7.5 \\
$0.71-0.80$ & 72 & 60.0 \\
$0.81-0.90$ & 26 & 21.7 \\
$0.91-1.00$ & 4 & 3.3 \\
Total & 120 & 100.0 \\
Minimum $=0.47$ & & \\
Mean $=0.67$ & & \\
Maximum $=0.94$ & & \\
\hline
\end{tabular}

\subsection{Returns to Scale}

The result of the Returns to Scale of cassava production in the study area is presented in Table 4 . Table 4 shows the elasticity and returns to scale of cassava production. The returns to scale indicate what would happen to output if all the inputs are increased at the same time. The result of the estimated model shows that the output elasticity was 1.306 .

Table 4. Elasticities and return to scale of the parameter of stochastic frontier production function

\begin{tabular}{ll}
\hline Variables & Elasticities \\
\hline Farm size & 0.437 \\
Labour & 0,210 \\
Planting materials & 0.516 \\
Capital & 0.143 \\
RTS & 1.306 \\
\hline
\end{tabular}


Technical efficiency and profitability of cassava production in Delta State: A stochastic frontier production function analysis

The result of this study shows that one unit increase in the quantities of the inputs would cause output to increase at an increasing rate. This infers that the surveyed cassava farmers were producing at an increasing return to scale. This denotes that a unit increase in all the production resources put together would bring about more than unit increase in output of cassava. The cassava farmers are at the irrational stage of production -stage 1 implying that inputs were under-utilized by the cassava farmers. This suggested that cassava farmers could benefit from the economies of scale linked to increasing returns.

\subsection{Cost and return analysis of cassava production}

The profitability of cassava production was determined using the cost and return analysis as presented in Table 5. The result shows that the total revenue realized was $\$ 254,393.30$ with a total cost of production of $\$ 106,928.46$ per hectare, the net income per hectare was $\$ 147,464.84$ and a gross margin of $\$ 155,726.34$. It also reveals a benefit cost ratio of $\$ 2.38$ implying that for every one naira invested in cassava production a profit of $\$ 2.38 \mathrm{k}$ was realized from its sales. The result is congruent with Nzeh-Emeka and Ugwu (2014) findings in Ondo State, Nigeria that cassava farmers realized a net farm income of $\$ 347,510.00$ per hectare of cassava production.

Table 5. Cost and return analysis of cassava production

\begin{tabular}{lll}
\hline Cost/revenue items & Amount $(\mathrm{N} / \mathrm{ha})$ & Percentage \\
\hline Variable cost & & 11.5 \\
\hline Cuttings $(\mathrm{kg} / \mathrm{ha})$ & $12,327.22$ & 9.9 \\
Fertilizer(kg/ha) & $10,566.19$ & 3.3 \\
Herbicide (litre/ha) & $3,522.06$ & 6.6 \\
Transportation & $7,044.13$ & \\
Labour(A/ man days) & & \\
Land clearing & $15,283.10$ & \\
Tillage & $9,522.06$ & \\
Planting & 5039.70 & \\
Weeding & $25,283.10$ & \\
Fertilizer application & $2,519.85$ & 27.3 \\
Harvesting & $7,559.55$ & 92.3 \\
Total labour cost & $29,207.36$ & \\
Total variable cost & $98,666.96$ & \\
\hline Fixed cost & & \\
Land & $6,500.00$ & \\
Implements & $1,761.03$ & 100.0 \\
Total fixed cost & 8261.50 & \\
\hline Total cost & $106,928.46$ & \\
Total revenue & $254,393.30$ & \\
Net income & $147,464.84$ & \\
Gross margin & $155,726.34$ & \\
Benefit/cost ratio $(\mathrm{BCR})$ & 2.38 & \\
\hline
\end{tabular}

\subsection{Constraints of cassava production}

The constraints affecting cassava production is presented in Table 6. The result indicates that inadequate finance was the most pressing problem limiting cassava production and it accounted for $72.5 \%$ of the respondents. This finding is supported by Nmadu et al. (2015) who identified inadequate finance a constraining factor to active participation in agricultural activities in Ondo State, Nigeria. About $62.5 \%$ of them were affected by lack of access to credit, $61.7 \%$ faced problem relating to inadequate access to improved varieties and $59.2 \%$ had high cost of input problem because of poor financial resources. This implies that most of the farmers had problem of procuring inputs such as improved cassava cuttings and fertilizer because they depend on their personal savings for cassava production. The farmers pointed out that inadequate processing facilities $(55.8 \%)$ and inadequate storage facilities $(54.2 \%)$ was a serious problem in cassava production. About $47.5 \%$ agreed that transportation was also a challenge in cassava production. 
Table 6. Constraints of cassava production

\begin{tabular}{llll}
\hline Constraint & Frequency & Percentage & Ranking \\
\hline Inadequate finance & 87 & 72.5 & $1^{\text {st }}$ \\
High input cost & 71 & 59.2 & $4^{\text {th }}$ \\
Access to credit & 75 & 62.5 & $2^{\text {nd }}$ \\
Labour & 38 & 31.7 & $9^{\text {th }}$ \\
Inadequate extension services & 52 & 43.3 & $8^{\text {th }}$ \\
Transportation & 57 & 47.5 & 7 th \\
Inadequate storage facilities & 65 & 54.2 & 6 th \\
Inadequate access to improved varieties & 74 & 61.7 & 3 rd \\
Pest and disease & 34 & 28.3 & 10 th \\
Inadequate processing facilities & 67 & 55.8 & 5 th \\
Poor marketing outlets & 28 & 23.3 & 11 th \\
\hline
\end{tabular}

Multiple responses

\section{Conclusions}

The farmers were inefficient in the use of a given technology or mix of inputs but can attain optimum efficiency at the frontier line by a $33 \%$ increase. The major factors which influenced the farmers technical efficiency were farm size, planting material and capital while farming experience, level of education, access to credit, gender, age of farmer and household size exerted a significant effect on their inefficiency level. The major problems faced by the farmers were inadequate finance, inaccessibility to credit, inadequate access to improved varieties and high cost of inputs. It is therefore recommended that the farmers should join cooperative society to facilitate access to credit from financial institutions, acquire inputs at a subsidized rate and other forms of assistance from the government. Apart from the provision of basic production inputs to cassava farmers, effort should be directed towards intensive research and introduction of improved cassava production technologies. There is also need to establish adequate storage and processing facilities to further boost cassava utilization. Finally, considering the farm size cultivated by the farmers, the study recommends the expansion of cassava farmland. 


\section{References}

Agbontale, A. O., Issa, F.O. (2011). Agricultural knowledge information system (AKIS) in Nigeria: practice, challenges and solutions. Journal of Sustainable Development, 8(1/2):66-74

Ahmed-Hameed, A., Sharkdam, W. (2017). Leading Pan-Africanism and Development: Nigeria's Role in the New Partnership for Africa's Development (NEPAD).IUP Journal of International Relations; Hyderabad, 11(4):49-73.

Akerele, E.O., Onasanya, A.S., Dada, O.M., Odio, A.F. (2018). Technical Efficiency of Ofada Rice Producers in Ogun State, Nigeria. KIU Journal of Humanities, 3(3): 125-138.

Anyanwu, C.N., Ibeto, C.N., Ezeoha, S.L., Ogbuagu, N.J. (2015). Sustainability of cassava (Manihot esculenta Crantz) as industrial feedstock, energy and food crop in Nigeria. Renewable Energy, 81:745-752.

Battese, G.E., Coelli, T.J. (1995). A Model for, Technical Inefficiency Effects in a Stochastic Frontiers Production Function for Panel Data. Empirical Economics, 20: 325-332.

Berhanu, K., Beliyu, L (2015). Women Farmers in Practices: Opportunities and Challenges in Accessing Potato Production Technologies in Welmera Ethiopia. Asian Journal of Agricultural Extension, Economics and Sociology, 6(3): 149-157.

Coelli, T.J. (1996). A Guide to Frontier Version 4.Ic: a Computer Programme for Stochastic Frontier' Production and Cost Function Estimation". Working Paper 96/07, Centre' for Efficiency and Productivity Analysis, Department of Econometrics, University of New England, Armidale, Australia.

Durojaiye A. M., Ogunjinmi, O. O (2015). Technical Efficiency Analysis of Mechanized Cassava Farmers in Afijio Local Government Area of Oyo State, Nigeria. Global Journal Biology, Agriculture and Health Sciences,4 (3):113-117.

Ekunwe, P.A., Henri-Ukoha, A., Emmanuel, R. (2018). Technical Efficiency and Return to Scale in Yam Production in Tai Local Government Area of Rivers State, Nigeria. Advances in Research, 15(2): 1-9.

Ezeibe, A. B., Edafiogho, D. O, Okonkwo, N. A., Okide, C. C. (2015).Gender differences and challenges in cassava production and processing in Abia State, Nigeria. African Journal of Agricultural Research, 10(22): 2259-2266.

Fan, M., Shen, J., Yuan, L., Jiang, R., Chen., X., Davis, W.J., Zhang, F. (2012). Improving crop productivity and resource use efficiency to ensure food security and environmental quality in China. Journal of Experimental Botany, 63(1):13-24

FAO (2013). Food and Agriculture Organization of the United Nations. Statistical Database _ FAOSTAT, http:/faostat.fao.org/; 2013 (Accessed 24 August 2018)

Girei A. A., Dire, B., Yuguda., R.M., Salihu, M. (2014). Analysis of Productivity and Technical Efficiency of Cassava Production in ArdoKola and Gassol Local Government Areas of Taraba State, Nigeria. Agriculture, Forestry and Fisheries, 3(1): 1- 5.

Idrisa, Y.L.; Shehu, H., Ngamdu, M.B. (2012). Effect of Adoption of improved maize seed on household food security in Gwoza Local Government Area of Borno State Nigeria. Global Journal, 12( 5).

IITA (2010). Post Harvest Technology Annual report. pp. 62-80.

Issa, F. O., Kagbu, J. H., Abdulkadir, S .(2016). Analysis of socio-economic factors influencing farmers' adoption of improved maize production practices in Ikara local government area of Kaduna state, Nigeria. Agrosearch, 16( 2): 15-24.

Kamaljit, K., Preeti. A. (2017). Cassava as Potential Crop for the Food and Fermentation Industry: A review. International Journal of Food Fermentation Technology, 7(1): 1-12.

Komolafe, S. E., Adeseji, G. B., Ajibola, B.O. (2014). Determinant of adoption of improved crop practices among women farmers in Ekiti East L.G.A. of Ekiti, Nigeria. Journal of Agricultural Research, 5(2): 22-31.

Krishna, H. K., Mishra, A., Mohanty, S. (2016). Impact of land ownership on productivity and efficiency of rice farmers: The case of the Philippines. Land Use Policy, 50:371-378

Kumbhakar, S. C., Lovell, C. A. K. (2000). Stochastic Frontier Analysis. Cambridge University Press, Cambridge.

Nmadu, J.N., Halima, S., Omojeso, B.V. (2015). Socio-economic factors affecting adoption of innovations by cocoa farmers in Ondo State, Nigeria. European Journal of Business, Economics and Accountancy, 3 (2):58-66.

Ogunyinka, E.O., Ajibefun, I.A. (2003). Determinants of Technical Inefficiency of Farm Production: Tobit Analysis Approach to the NDE Farmers in Ondo State, Nigeria. International Journal of Agriculture and Biology, 6 (2): 355-358.

Ojimba, T.P .(2017). Cost of Production and Resource - Use Efficiency among Small Scale Cassava Farmers in Igbo Etche Rivers State, Nigeria. Direct Research Journal of Agriculture and Food Science, 5 (12):390-400.

Onyedicachi, A. C. (2015). The effect of social capital on access to micro credit among rural farming households in Abia State, Nigeria. Agrosearch 15(1): $59-75$.

Onyenwoke C. A., Simonyan, K. J. (2014). African Journal of Agricultural Research Cassava post-harvest processing and storage in Nigeria: A review. African Journal of Agricultural Research, 9(53):3853-3863. 
JOTAF/ Journal of Tekirdag Agricultural Faculty, 2021, 18(1)

Osun T, Ogundijo S. D., Bolariwa, K.O. (2014). Technical Efficiency Analysis of Cassava Production in Nigeria; Implication for Increased Productivity and Competitiveness. Research Journal of Agriculture and Environmental Management, 3(11):569-576.

Yakubu, M., Akanegbu, B. (2015). Neglecting agriculture and its consequences to the Nigerian economy: an analytical synthesis. European Journal of Research in Social Sciences, 3 (3) :18-27. 